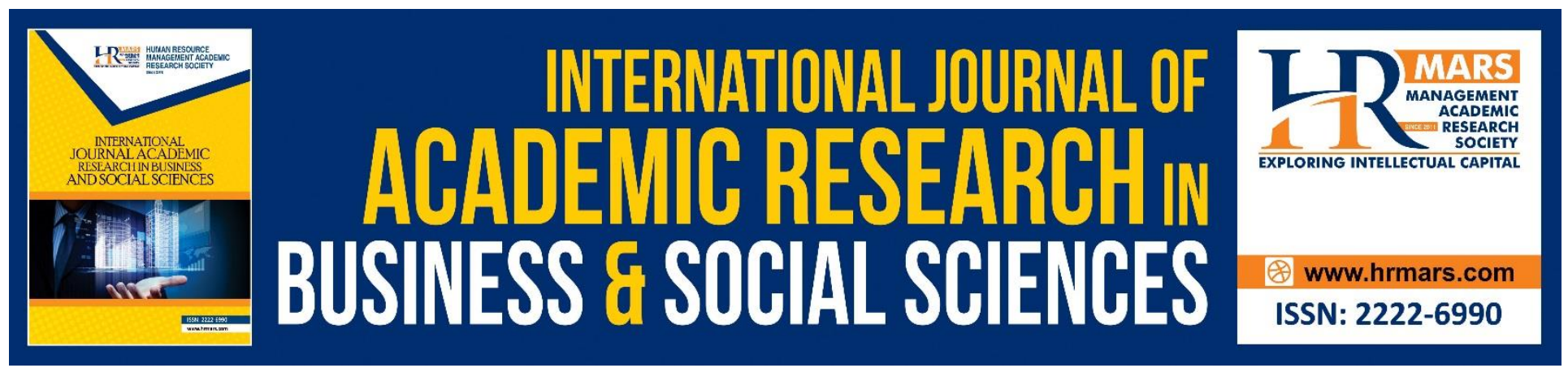

\title{
Macroeconomics Determinants of Non-Performing Loans in Malaysia: An ARDL Approach
}

Jalis Md Zainol, Amirudin Mohd Nor, Siti Nurulhuda Ibrahim, Shahreena Daud

To Link this Article: http://dx.doi.org/10.6007/IJARBSS/v8-i10/4773

DOI: 10.6007/IJARBSS/v8-i10/4773

Received: 11 Sept 2018, Revised: 25 Oct 2018, Accepted: 28 Oct 2018

Published Online: 31 October 2018

In-Text Citation: (Zainol, Nor, Ibrahim, \& Daud, 2018)

To Cite this Article: Zainol, J. M., Nor, A. M., Ibrahim, S. N., \& Daud, S. (2018). Macroeconomics Determinants of Non-Performing Loans in Malaysia: An ARDL Approach. International Journal of Academic Research in

Business and Social Sciences, 8(10), 692-706.

Copyright: (C) 2018 The Author(s)

Published by Human Resource Management Academic Research Society (www.hrmars.com)

This article is published under the Creative Commons Attribution (CC BY 4.0) license. Anyone may reproduce, distribute, translate and create derivative works of this article (for both commercial and non-commercial purposes), subject to full attribution to the original publication and authors. The full terms of this license may be seen

at: http://creativecommons.org/licences/by/4.0/legalcode

Vol. 8, No. 10, 2018, Pg. 692 - 706

http://hrmars.com/index.php/pages/detail/IJARBSS

JOURNAL HOMEPAGE

Full Terms \& Conditions of access and use can be found at http://hrmars.com/index.php/pages/detail/publication-ethics 


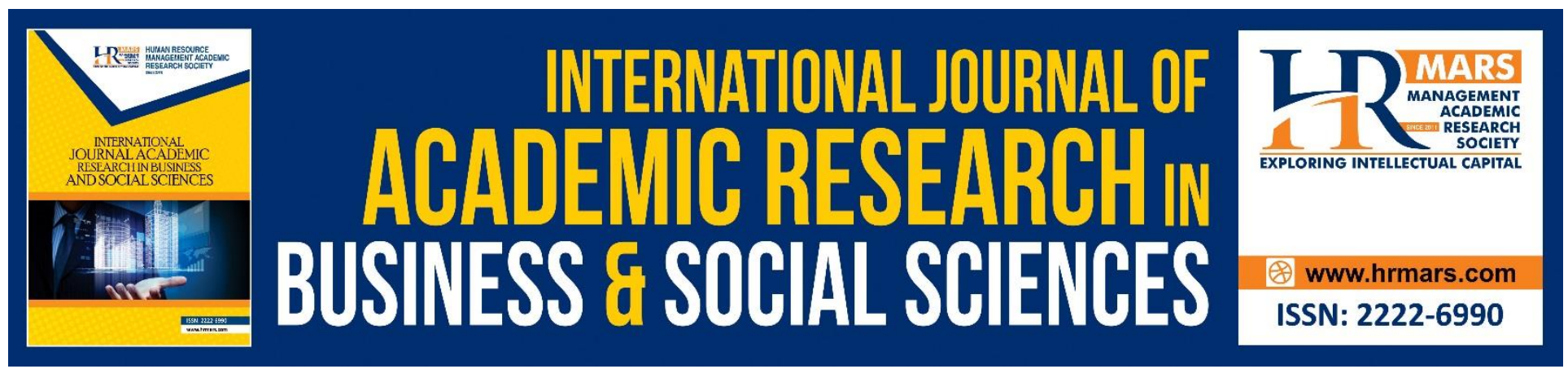

\title{
Macroeconomics Determinants of Non-Performing Loans in Malaysia: An ARDL Approach
}

\author{
Jalis Md Zainol ${ }^{1}$, Amirudin Mohd Nor ${ }^{1}$, Siti Nurulhuda Ibrahim¹, \\ Shahreena Daud ${ }^{1}$ \\ ${ }^{1}$ Faculty of Business and Management, Universiti Teknologi MARA, Melaka, Malaysia
}

\begin{abstract}
This paper empirically studies the macroeconomic factors determining the non-performing loans (NPLs) of the banking and financial institutions in Malaysia. Using a set of time series data from Q12006 to Q42015, Auto-Regressive Distributed Lag (ARDL) method was employed to discover the significant relationships between the variables in the long run as well as short run elasticity within the model. The study concludes that the level of NPLs in Malaysia is affected by Malaysian macroeconomic variables namely Gross Domestic Product (GDP), Base Lending Rate (BLR), Inflation (INF) and Household Income Distribution (ID). The result implies that GDP is significant and negatively affect NPLs, meanwhile BLR and ID are significant and positively related to NPLs, in line with the expected results. Nonetheless, INF resulted in insignificant relationship with NPLs contrary to our expectation. The result of this research is useful to assist financial institutions and the regulators for policy formulation so as to minimize the negative effects of NPLs to the Malaysian financial system.
\end{abstract} Keywords: Non-performing Loans (NPLS), Banking Institutions, Auto-Regressive Distributed Lag $(A R D L)$, Malaysia

\section{Introduction}

Asian financial crisis in 1997 has prompted a wave of research to identify the determinants of nonperforming loans (NPLs). It sparks researchers interest due to the evergreen nature of NPLs that move along with the economic cycles. Gaganis, Pasiouras, Doumpos, \& Zopounidis (2010) posit that there are four factors affecting banking stability which are regulations, attributes of banking and financial sector, situation of an institutions and the macroeconomic condition. On the same note, Bebczuk \& Cavallo (2016) states that the ability of bank to maintain its financial obligations and stability depends on customers capability and willingness to repay their debts, its influence by the economics policy and regulations of central bank. Bank failures in developing countries are caused by financial crises and are found to be significant with the percentage of NPLs during economic downturn. The strength and stability of the banks can be evaluated by many factors and one of them is the unperformed loans in the banking and financial institutions. The possibility of bankruptcy of these institutions can be determined by evaluating their level of NPLs. 
Generally, NPLs can be defined as bad debts. It is a default in payment where the bank has not received any payment from the borrower for over 3 months or during the maturity date agreed as stated in the loan agreement. In addition, NPLs can also be considered should: (i) loans that do not generate income for long period of time, or the principal and or the amount of interest charge on loans have not been paid for at least 90 days (Fofack, 2005), (ii) principal settlement or interest settlements can be considered "Poor" if unsettled for 90 days, "Doubtful" if unsettled for 180 days and "Loss" if unsettled after 1 year. At this instance, there is reasonable evidence doubting the payments to be settled in full.

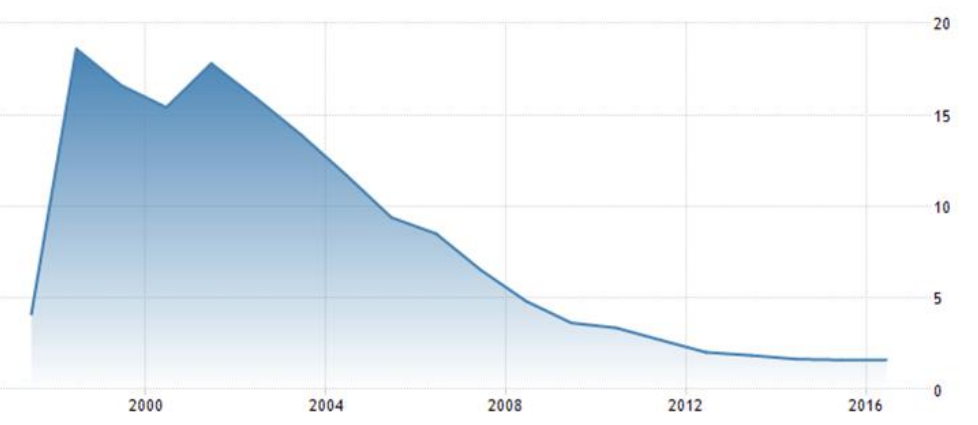

Figure 1: Banking and financial institutions NPLs in Malaysia in percentage (Source: World Bank) In Malaysia, bulk of the NPLs come from the business sector followed by the household sector with a proportion of $56 \%$ and $41 \%$ respectively. Most of the households borrow money from the bank for the purpose of education, health and investment activity. The percentage of NPLs in Malaysian banking system has declined gradually since the Asian financial crisis from a high of $13.60 \%$ in December 1998 to $3.2 \%$ in 2007. Nevertheless, NPLs problem went up slightly in 2008 and declined constantly until 2016. Effort has been made to identify the factors that influence the NPLs during these financial crisis as these factors are important for central bank, banking and financial institutions to help them establish policies that can improve banking institution's performance (Sufian, Kamarudin, \& Nassir, 2016). Until today, the bank maintains their efficiency by continuously revising their policy as a tool to face the economic problem and achieving their objective (Ismail, Azlan, Husin, Ishak, \& Hashim, 2017).

Economic conditions play an important role for the bank to maintain its performance. Banks in Malaysia must provide guidelines and regulations to prevent or solve potential problems that might occur out of its lending activities. Good performance of the banking system can boost the economic conditions of the country. The banking institutions such as commercial banks play an important role as sources of credit and as an economic agent. As mentioned previously, macroeconomic variables can influence the sensitivity of the non-performing loan. Bad debt can pose huge problems to the bank by negatively affecting bank results and performance that would lead to banking crisis. To examine the factors that affect NPLs in Malaysia, the researcher used multiple linear regressions as a method to acquire the results. It was found that GDP growth rate, base lending rate, inflation rate and household income distribution, as the macroeconomic variables that have strong effect on the level of NPLs.

Previous studies show inconclusive results in the relationship between macroeconomic variables and NPLs, specifically the inflation and household income distribution variables. Hence, this raised the interest of examining the actual relationship between these variables. This study is conducted with 
the intention to know how far macroeconomic variables can influence NPLs. Subsequently, the general objective of this paper is to determine the significant relationship between non-performing loan and the independent variables in Malaysia from year Q12006 to Q42015. The specific objectives are to determine the significant relationship between GDP growth, inflation rate, base lending rate and household income distribution towards the non-performing loans of banking and financial institutions in Malaysia from Q12006 to Q42015. In this paper, we adopt the Auto-Regressive Distributed Lag (ARDL) method to meet the abovementioned objectives.

This study contributes to individual borrowers and financial institutions (Fls) by providing additional information on their decision before applying for bank loans while financial institutions can analyze and identify the problems that can cause NPLs. The results can also assist Fls to prepare and adjust their lending policy in hope of preventing the FIs from having a large amount of NPLs in their portfolios.

The rest of the paper is structured as follows. In the next section, we highlight related empirical literature. Next, we outline our empirical approach and data. We employ the ARDL method to determine the relationship between macroeconomics variables and NPLs. We then proceed to present the estimation results and lastly, the final section concludes the main findings of the study.

\section{LITERATURE REVIEW}

Credit risk affects profitability, success and sustainability of financial institutions' future development and survival. Banks and financial institutions have to ensure full settlement of the loans granted in order to avoid this credit risk. There are two concerns for this risk which are macroeconomic factors and bank specific factors. It is not uncommon for banking institutions to use non-performing loans as a tool to measure the credit risk faced by the related parties. Klein (2013) has done a research in Europe and found that NPLs for the period of 1998-2011 is very much related to macroeconomic circumstances. The research states that the level of bad loans is influenced by the macroeconomic circumstances and several banks' factors. Previous findings in the literature analyzing the relationship of macro-financial conditions towards NPL indicate a positive impact to NPL. Macro-financial conditions played a key role in forecasting of banking crises and one of them is by using the NPLs.

\section{Macroeconomic factors toward Non-Performing Loan}

Gross Domestic Products: The literature reviews anonymously found that there is a negative relationship between actual GDP and NPLs (Fofack, 2005; Jakubík \& Reininger, 2014; Jiménez \& Saurina, 2006; Khemraj, Tarron \& Pasha, 2009; Louzis, Vouldis, \& Metaxas, 2012). The relationship can be interpreted by an increase in the level of actual GDP growth influence positively the level of profits in line with the decrease in NPLs. In this situation, the repayment capacity of the borrower is increased thus directly solve the bad debts issues. Contrary, collapse in the economy; decrease or adverse growth of GDP leads to unsettle debts.

Inflation: A number of studies have discovered the positive relationship between inflation and NPLS (Badar \& Yasmin, 2013; Fofack, 2005; Nkusu, 2011; Skarica, 2014). Badar \& Yasmin (2013) have conducted a study of banking institutions in Pakistan from the period of January 2002 until December 2011 measuring the long and short run between non-performing loans and variables such as inflation, exchange rate, interest rate, GDP and money supply. The ability of the borrowers to repay of their 
debts can be influenced by level of inflation and percentage of interest rate. For example, if the country is facing high level of inflation, the borrowers have difficulty to make repayment for their loans due to increasing cost of capital. Fofack (2005) also cites that higher level of inflation would result in costly borrowing and finally affects the quality of loan diversification. This is supported by Skarica (2014) who analyze banking institutions in Europe and found that higher inflation will reduce the income of household and incidentally influence the capability of debtors. On the other hand, Shingjergji (2013) opine that inflation has negative relationship in which high level of inflation can reduce the NPLs problem in the banking sector. A study done in Albanian's banking system concludes that when inflation is high in certain period, it will reduce the number of NPLs in the country. High level of inflation will decrease the value of debt and loans servicing will become easier as high rate of inflation can decrease the quantity of the loans. Therefore, high level of inflation will increase the credibility of the borrowers.

Lending Rates: The cause of rising NPLs is also due to the increase in lending rates (Badar \& Yasmin, 2013; Beck, Jakubik, \& Piloiu, 2013; Farhan, Sattar, Chaudhry, \& Khalil, 2012; Louzis et al., 2012; Nkusu, 2011). Fofack (2005) posits that the financial system will face financial crisis due to high interest rates and moral hazard of the borrowers. Increase in the lending rate would increase the loan servicing commitment, reduce the capability of borrowers to make repayment of the loans a burden the customers. Farhan et al. (2012) discover that lending rates have a positive relationship with NPLs. Using log-linear regression model on data collected from United States' commercial banks between 1984 until 1987, the researchers shows that NPLs is strongly affected by high lending interest rate. During economic downturn, unsettle loans problem may extremely arise due to problem of loan collections. Thus, this problem will reduce the ability of banks to grant more credits while cost of borrowings will increase too because of the bank's high lending rate. In a different set up, Badar \& Yasmin (2013) assert that there is significant positive relationship and long-term effect on Islamic banks in Malaysia.

Household Income Distribution: Using DRSL and DRNB model, Blanco \& Gimeno (2012) conclude that the variables that positively influence NPLs includes interest rates, amount of debt and household income distribution. The researchers state that high level of household income distribution leads to higher level of indebtedness. On the same note, Bayoumi \& Melander (2008) examine bank solvency based on macroeconomic factors that affect the financial system. Declining in loan quality is caused by the reduction of economic conditions and household income and subsequently increases the level of bad debts. Bad debts on the other hand reduces the credit institution's capital thus compacting capital capability ratio. For the bank's recapitalization, banking institutions should re-examine loans supply by monitoring the credit criterions for the borrowers. Nevertheless, during economic recession, there is negative relationship between NPLs and household income distribution. This is because the increase in interest rate will burden the borrowers thus increasing the default loan ratios. Another related study by Skarica (2014) also discovers a negative relationship when borrower's income is falling and number of NPLs problem arise. Increase in the level of inflation reduces the actual income, thus affecting borrowers' capability on loan repayment. During high recession, it will decrease the borrower's capacity on loan-servicing.

The above literatures pointed to an inconclusive results in the relationship between macroeconomic variables and NPLs, specifically the inflation and household income distribution variables towards 
NPLs, thus raised the interest of examining the actual relationship between these variables. Although GDP and lending rate is consistent in terms of results over time, it is also worth to look at the current standing of both variables at the current situation whether the results hold or otherwise.

This paper adds to the existing NPLs literature by considering the macroeconomic determinants of NPLs in the Malaysian environment using the ARDL approach. Based on the aforesaid literature, we use the real GDP, inflation, lending rate and household income distribution as our macroeconomic variables.

\section{MODEL AND DATA}

\section{Model}

The model used in this study gives priority to the econometric models representing the four pillars of NPLs namely base lending rate, inflation rate, gross domestic product and income distribution. The model is developed based on the research objective i.e to determine the significant relationship between non-performing loans and the macroeconomic variables in Malaysia. Thus, the objective is to test the impacts of macroeconomic variable such as base lending rate (BLR), inflation rate (INF), gross domestic product (GDP) and income distribution (ID) on non-performing loans (NPLs). These variables were selected based on the related literature as it played significant roles in determining non-performing loans in Malaysia. The study also tries to find the long run and short run elasticities within the model. Table 1 gives the description of the data, sources of the data and the expected signs of the variables used.

Table 1: Description of variables

\begin{tabular}{|c|c|c|c|c|c|}
\hline $\begin{array}{l}\text { Dependent } \\
\text { variable }\end{array}$ & Related Literature & $\begin{array}{l}\text { Description } \\
\text { (Quarterly) }\end{array}$ & $\begin{array}{c}\text { Symbo } \\
\text { I }\end{array}$ & $\begin{array}{c}\text { Sourc } \\
\text { e }\end{array}$ & $\begin{array}{c}\text { Expecte } \\
\text { d Sign }\end{array}$ \\
\hline $\begin{array}{l}\text { Non-Performing } \\
\text { Loan }\end{array}$ & Beck et al (2013); Klein (2013) & $\begin{array}{l}\text { NPF/ total } \\
\text { loan }\end{array}$ & NPL & CBM & - \\
\hline \multicolumn{6}{|c|}{ Independent variables } \\
\hline $\begin{array}{l}\text { Gross Domestic } \\
\text { Products }\end{array}$ & $\begin{array}{c}\text { Fofack (2005); Khemraj, Tarron } \\
\text { \& Pasha, (2009) }\end{array}$ & $\begin{array}{l}\text { GDP Per } \\
\text { Capita }\end{array}$ & GDP & DOSM & -ve \\
\hline Inflation & $\begin{array}{c}\text { Badar \& Yasmin (2013); Skarica } \\
\text { (2014) }\end{array}$ & $\begin{array}{l}\text { Consumer } \\
\text { Price Index }\end{array}$ & $\mathrm{CPI}$ & DOSM & + ve/-ve \\
\hline $\begin{array}{l}\text { Household } \\
\text { Income }\end{array}$ & $\begin{array}{c}\text { Bayoumi \& Melander (2008; } \\
\text { Skarica (2014) }\end{array}$ & $\begin{array}{l}\text { Household } \\
\text { Income } \\
\text { Distribution }\end{array}$ & ID & DOSM & +ve/ -ve \\
\hline Lending Rate & $\begin{array}{c}\text { Badar \& Yasmin (2013); Louzis } \\
\text { et al. (2012) }\end{array}$ & $\begin{array}{c}\text { Base } \\
\text { Lending } \\
\text { Rate }\end{array}$ & BLR & CBM & + ve \\
\hline
\end{tabular}

Note: DOSM is Department of Statistics Malaysia. CBM is the Central Bank of Malaysia

In this empirical study, we adopt the ARDL approach to look the relationship between NPLs and Malaysian macroeconomic variables. We proceed to follow the general econometric process in stages. We started off with the unit root test using the Augmented Dickey-Fuller (ADF) unit root test and Phillips-Perron (PP) unit root test. The purpose of the unit root test is to determine either the 
variable is stationary at level, I (0) or at first difference, I (1). Nevertheless, the presence of integrated stochastic trend of I (2) will crash this technique and therefore must be avoided (Nkoro \& Uko, 2016). In the next section, we discuss on the model specification, estimation techniques, Autoregressive Distributed Lag (ARDL) Cointegration for time series analysis and the transformation of ARDL Model. Diagnostic tests were also performed to test the adequacy and closeness of fit of the empirical model to the data. We proceed to perform the LM test for autocorrelation, Jarque Bera test for normality test, hateroscedasticity test, Ramsey RESET test for functional form misspecification and Cumulative Sum (CUSUM) and Cumulative Sum of Square (CUSUMSQ) Stability Test for parameter consistency.

\section{Model Specification: Determination of Non-Performing Loans Movement}

The general form of the empirical model as introduced by Gauss Markov is as follows:

$$
N P L_{t}=f\left(+G D P_{t}+B L R_{t}+I N F_{t}+I D_{t}\right)
$$

Where NPL is Non-Performing Loans, GDP is Gross Domestic Product, BLR is Base Lending Rate, INF is Inflation Rate, and ID is Income Distributions. The log version for the NPL model introduced in this study is as follows:

$$
L N N P L_{i t}=\alpha_{0}+\beta_{1} L N G D P_{i t}+\beta_{2} L_{N I N F_{i t}}+\beta_{3} L N B L R_{i t}+\beta_{4} L N I D_{i t}+\varepsilon_{t}
$$

Where NPL is non-performing loans measured by non-performing loans to gross loan, INF is inflation rate measured by consumer price index (quarterly \%), GDP is gross domestic product per capita (constant 2015 RM), BLR is base lending rate and ID is income distribution measured on data collected by Household sector in Malaysia (quarterly \%). GDP coefficient is expected to have negative sign, BLR is expected to have positive sign while the other two coefficients, INF and ID would result in either positive or negative.

\section{Autoregressive Distributed Lag (ARDL) Cointegration for Time Series Analysis}

Testing the existence of cointegration among economic variable is very important in econometric analysis. The existence of cointegration among variables not only shows a long-run equilibrium relationship between variables but also it can guarantee the employing of Ordinary Least Square (OLS) method for estimation of the coefficients as consistent results are accepted. Previous studies show that various methods are available in conducting the cointegration analysis, including the residual-based approach proposed by Engle and Granger (1987), the maximum likelihood-based approach proposed by Johansen and Juselius (1990), the fully modified OLS procedures of Phillips and Hansen (1990) and the recently developed approach, Autoregressive Distributed Lag (ARDL) suggested by Pesaran, Shin, \& Smith (2001).

The ARDL approach involves estimating the conditional error correction version of the ARDL model for the variable underestimation. The equation of extended ARDL ( $p, q 1, q 2, \ldots q k)$ is being modelled as given below (Pesaran et al., 2001):

$$
\alpha(L, p) y_{t}=\alpha_{0}+\sum_{i=1}^{k} \beta_{i}(L, p) x_{i t}+\lambda^{\prime} w_{t}+\varepsilon_{t}
$$

$\forall t=1, \ldots, n$ 
Where

$$
\begin{aligned}
& \alpha(L, p)=1-\alpha_{1} L-\alpha_{2} L^{2}-\ldots-\alpha_{p} L^{p} \\
& \beta_{i}\left(L, q_{i}\right)=\beta_{i^{o}}+\beta_{i 1} L+\beta_{i 2} L^{2}+\ldots+\beta_{i q_{i}} L^{q t} \forall_{t} i=1,2 \ldots, k
\end{aligned}
$$

$\mathrm{y}_{\mathrm{t}}$ is a dependent variable, $\alpha_{0}$ is the constant term, $\mathrm{L}$ is the lag operator such that $\mathrm{L}_{\mathrm{t}}=\mathrm{y}_{\mathrm{t}-1}$, is $\mathrm{s} \times 1$ vector of deterministic variables such as intercept term, time trends, or exogenous variables with fixed lags. The long-term elasticities are estimated by:

$$
\phi_{i}=\frac{\hat{\beta}_{i}(1, \hat{q})}{\alpha(1, \hat{p})}=\frac{\hat{\beta}_{i o}+\hat{\beta}_{i 1}+\ldots+\hat{\beta}_{i \hat{q}}}{1-\hat{\alpha}_{1}-\hat{\alpha}_{2}-\ldots-\hat{\alpha}_{p}}
$$

$\forall i=1,2 \ldots, k$

where ${ }^{\wedge} p$ and ${ }^{\wedge} q i, i=1,2, \ldots k$ are the selected (estimated) values of ${ }^{\wedge} p$ and ${ }^{\wedge} q i, i=1,2, \ldots, k$.

The long run coefficients are estimated by:

$$
\pi=\frac{\hat{\lambda}\left(\hat{p}, \hat{q}_{1}, \hat{q}_{2} \ldots, \hat{q_{k}}\right)}{1-\hat{\alpha}_{1}-\hat{\alpha}_{2}-\ldots-\hat{\alpha}_{p}}
$$

where ${ }^{\wedge} \lambda(\wedge p, \wedge q 1, \wedge q 2, \ldots, \wedge q k)$ denotes the OLS estimates of $\lambda$ in the equation (i) for the selected ARDL model. The error correction model (ECM) of the ARDL version (^p, ^q1, ^q2, ., ^qk) is being obtained in terms of lagged levels and the first difference of $y_{t}, x_{1 t}, x_{2 t}, \ldots, x_{k t}$ and $w_{t}$ :

$$
\Delta y_{t}=\Delta \alpha_{0}-\alpha(1, \hat{p}) E C_{t-1}+\sum_{i=1}^{k} \beta_{i o} \Delta x_{i t}+\lambda^{\prime} \Delta w_{t}-\sum_{j=1}^{p-1} \alpha \cdot j \Delta y_{t-1}-\sum_{i=1}^{k} \sum_{j=1}^{q-1} \beta_{i j} \Delta x_{i, t-j}+\varepsilon_{t}
$$

where ECM is the error correction model, and it is defined as follows:

$$
E C M_{t}=y_{t}-\alpha-\sum \hat{\beta}_{i} x_{i t}-\lambda^{\prime} w_{t}
$$

$\mathrm{x}_{\mathrm{t}}$ is the $\mathrm{k}$ - dimensional forcing variables which are not co-integrated among themselves. $\varepsilon_{\mathrm{t}}$ is a vector of stochastic error terms, with zero means and constant variance-covariance. An error correction term among cointegrated variables shows the changes in the dependent variable. These changes are not only the function of both the levels of disequilibrium in the cointegration relationship but also in the other explanatory variables. This indicates the deviation in dependent variable from a short span of time to long run equilibrium relationship (Masih \& Masih, 1997).

The ARDL bound testing approach to cointegration has better properties for small data sample. ARDL approach to cointegration provides better results for a small sample data set as compared to traditional approaches such as the Engle \& Granger (1987), the Johansen \& Juselius (1990) and Phillips 
\& Hansen (1990) methods. These approaches require that all the series should have unique order of integration. In addition, unrestricted error correction model (UECM) is derived from the ARDL model using simple linear specification, which integrates both long-run as well as short-run dynamics. The UECM model does not seem to lose information about long-run relation. Another advantage of the ARDL bound testing approach is that the unrestricted model of ECM accommodates lags that capture the data generating process in a general-to-specific. This method is favored over the traditional regression method because the regression approach only captures short term, cyclical or seasonal effects. In other words, the regression is not really testing long term (theoretical) relationships. Moreover, in traditional regression, the endogeneity and exogeneity of variables is pre-determined by the researcher, usually on the basis of prevailing or a priori theories. Also, cointegration techniques embrace the dynamic interaction between variables whereas traditional regression methods, by definition, exclude or discriminate against interaction between variables.

\section{The Transformation of ARDL Model}

In order to perform ARDL bound F test for examining the existence of long-run relationship, an ARDL equation called as Unrestricted Error Correction Model (UECM) is constructed for all proposed model from research objectives.

The transformation of all models is listed below:

$$
\begin{aligned}
& \Delta L N N P L_{t}=\beta_{0}+\theta_{0} L N N P L_{t-1}+\theta_{1} L N G D P_{t-1}+\theta_{2} L_{N I N F_{t-1}}+\theta_{3} L N B L R_{t-1}+\theta_{4} L N I D_{t-1} \\
& +\sum_{i=1}^{p} \beta_{i} \Delta L N N P L_{t-i}+\sum_{i=0}^{q} \gamma_{i} \Delta L N G D P_{t-i}+\sum_{i=0}^{r} \delta_{i} \Delta L N I N F_{t-i}+\sum_{i=0}^{s} \lambda_{i} \Delta L N B L R_{t-i}+\sum_{i=0}^{t} \vartheta_{i} \Delta L N I D_{t-i}+v_{t}
\end{aligned}
$$

where $\Delta$ is the first difference operator and $u_{t}$ is a white-noise disturbance term. Residuals for the UECM should be serially uncorrelated, and the model should be stable. The long run relationship hypotheses is $\mathrm{HO}$ : $\theta 0=\theta 1=\theta 2=\theta 3=0$ (there is no long-run relationship) and $\mathrm{H1}: \theta 0 \neq \theta 1 \neq \theta 2 \neq$ $\theta 3 \neq 0$ (there is a long-run relationship exists) which suggest the existence of cointegration among the variables. The presence of cointegration was based on F-statistic value. This F-statistic value is then compared with the critical value introduced by Pesaran et. al. (2001). If the estimated F-statistic is greater than the upper bound value of the table, we can reject the null hypothesis and accept the alternative hypothesis that cointegration exist. On the other hand, if F-statistic is lower than the lower bound, the null hypotheses cannot be rejected and thus the cointegration in the proposed model does not exist.

\section{Data and Diagnostic Tests}

Quarterly data over 19 years starting from 2006 until 2015 are used in the empirical analysis. The data were collected from various sources as listed in Table 1. In the analyses that follow, we take the natural logarithm of each variable. The time series data is then ran using E-Views 7 software by applying ARDL method for all estimations.

Diagnostics test is conducted to identify either all the variables used can give a trustworthy or undoubted result in a long run. Table 2 shows diagnostic statistics which suggest that the model is well identified. The summary in Table 2 indicates that the model is free from autocorrelation problem, have accurate functional form, the residuals is serially uncorrelated, and has no 
INTERNATIONAL JOURNAL OF ACADEMIC RESEARCH IN BUSINESS AND SOCIAL SCIENCES Vol. 8, No. 10, Oct. 2018, E-ISSN: 2222-6990 ㄷ 2018 HRMARS

homoscedastic problem. Serial correlation has 0.732 of $p$-value, RAMSEY Reset Test or functional has 0.343 of p-value, Normality has 0.671 of p-value and lastly, Heteroscedasticity has 0.653 of $p$-value. All of the results are above significant level of $10 \%$ and therefore failed to reject the null hypothesis (HO) as thus the diagnostic tests conclude that there is no problem with the model.

Table 2: Diagnostic Test Summary

\begin{tabular}{lcccc}
\hline Tests & LM test & RAMSEY Reset Test & Jarque Bera \\
Diagnostic & Serial correlation & Functional form & Hateroscedasticity \\
\hline Results & 0.316 & 0.942 & 0.795 & 0.819 \\
& $(0.732)$ & $(0.343)$ & $(0.671)$ & $(0.653)$ \\
\hline Hypothesis & HO=There is no & HO=The model is & HO= Residual are & HO=There is no \\
& autocorrelation & correctly specified & normally distributed & heteroscedasticity \\
\hline
\end{tabular}

a P-values are in parentheses.

*** Significant at 0.01 level, ** Significant at 0.05 level, * Significant at 0.10 level.

A test for structural stability is done through cumulative sum of recursive residuals (CUSUM) and the cumulative sum of recursive residuals of square (CUSUMSQ) so as to obtain a reliable and substantial results. Figure 2 depicts that the model shows stability in general as both CUSUM and CUSUMSQ move inside the critical bound and were at $5 \%$ significant level. In conclusion, the results show a complete verdict by using these models. The diagrams below show the illustration of both CUSUM and CUSUMSQ.
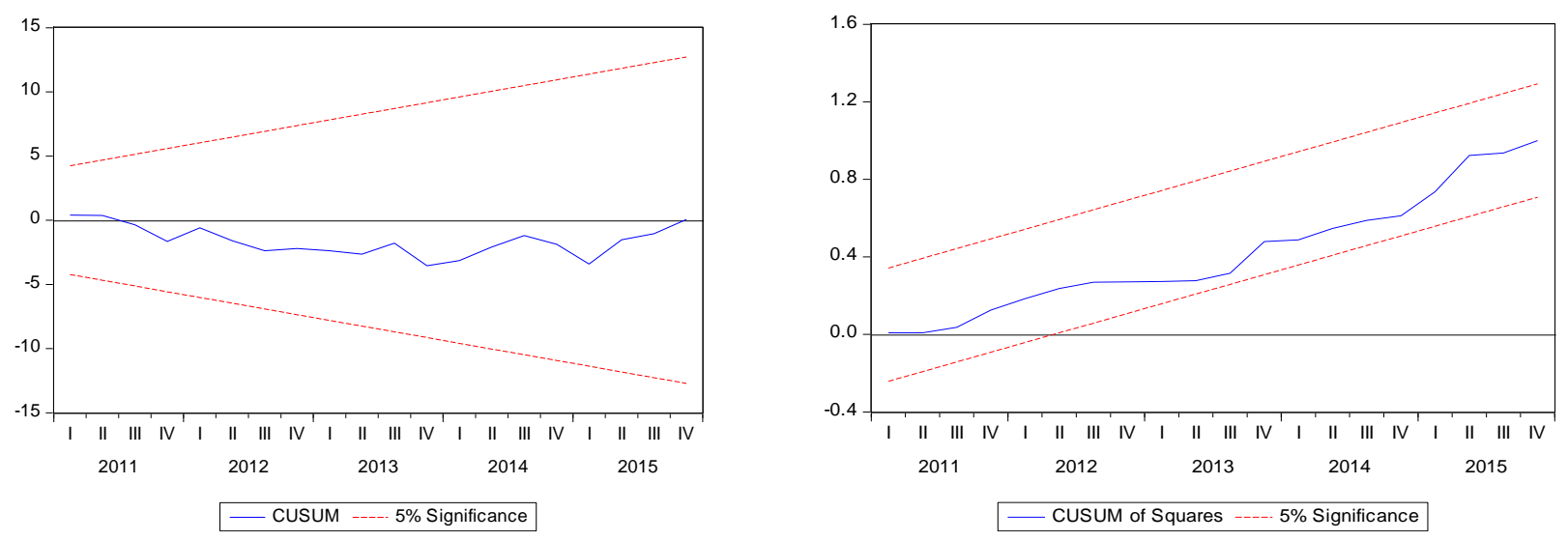

Figure 2: CUSUM and CUSUMSQ Stability Tests for Non-Performing Loans

\section{FINDINGS}

\section{ARDL Cointegration}

The results in Table 3 indicates a statistically significant long run cointegration between the variables. In this analysis, we use the maximum lag at 4 with an optimum order of 1,2,3,3,3 for Akaike Information Criteria (AIC). According to Narayan (2004), F-statistics need to be compared with the 
INTERNATIONAL JOURNAL OF ACADEMIC RESEARCH IN BUSINESS AND SOCIAL SCIENCES Vol. 8, No. 10, Oct. 2018, E-ISSN: 2222-6990 @ 2018 HRMARS

critical value provided. The results of cointegration showed that F-statistic (8.176976) obtained from the optimum lag is more than critical value of upper bound at $1 \%$ significant level thus supporting the existence of long term cointegration.

Table 3: ARDL Tests for Co-integration for Model of Non-Performing Loans

\begin{tabular}{|c|c|c|c|c|}
\hline Model & $\begin{array}{l}\text { Maximum lag } \\
\text { imposed }\end{array}$ & AIC & $\begin{array}{c}\text { F-Statistic at SIC- } \\
\text { Selected Optimal Lags }\end{array}$ & Result \\
\hline Malaysia & 4 & {$[1,2,3,3,3]$} & $8.176976 * * *$ & Cointegration Exist \\
\hline \multicolumn{3}{|c|}{ Critical Values for F-statistics ${ }^{\#}$} & Lower I(0) & Upper I(1) \\
\hline \multicolumn{3}{|l|}{$1 \%$} & 3.74 & 5.06 \\
\hline \multicolumn{3}{|l|}{$5 \% \quad k=5$} & 2.86 & 4.01 \\
\hline \multicolumn{3}{|l|}{$10 \%$} & 2.45 & 3.52 \\
\hline
\end{tabular}

Note: \# The critical values are obtained from E-views $9, \mathrm{k}$ is number of variables, critical values for the bounds test: case III: unrestricted intercept and no trend. $* * *, * *$, and $*$ represent $1 \%, 5 \%$ and $10 \%$ significant level respectively.

\section{Estimation Results: Estimation of Long Run Elasticities}

After satisfying the existence of cointegration between NPL and independent variables, we proceed to identify the relationship between all variables by adopting the cointegrated regression using ARDL method.

Table 4: Results of the Estimation of Long Run Elasticities and Long Run Coefficients

\begin{tabular}{ccccc}
\hline Variable & Coefficient & Std. Error & t-Statistic & Prob. \\
\hline LNGDP & -2.605699 & 0.070521 & -36.949033 & $0.0000^{* * *}$ \\
LNINF & -0.060384 & 0.073965 & -0.816381 & 0.4239 \\
LNBLR & 1.368489 & 0.273348 & 5.006404 & $0.0001^{* * *}$ \\
LNID & 0.086481 & 0.022225 & 3.891095 & $0.0009 * * *$ \\
C & 30.362249 & 0.951971 & 31.894087 & $0.0000^{* * *}$ \\
\hline
\end{tabular}

a P-values are in parentheses.

$* * *$ Significant at 0.01 level, ** Significant at 0.05 level, * Significant at 0.10 level.

Table 4 shows the long run elasticity of all the variables in the model. Gross Domestic Product, LNGDP, has a significant negative relationship with the dependent variable LNNPL, in line with our expectation. An increase by $1 \%$ of LNGDP will decrease LNNPL by $2.605 \%$ due to the negative coefficient. From the table, $p$-value shows that LNGDP is significant at $1 \%$ significant level. The result confirms the studies of Fofack (2005); Jiménez \& Saurina (2006); Khemraj, Tarron \& Pasha, (2009). In general, improvement in the economy of the country increases the capability of the borrower due to increase in income. In this instance, the borrowers are able to increase their financial stability, and subsequently able to repay their debts. Hence, NPLs portfolios of commercial banks can be reduced when there is improvement in the real economy. 
Base Lending Rate, LNBLR on the other hand shows a positive and significant relationship with LNNPL at a $1 \%$ significant level. An increase in LNBLR by $1 \%$ will increase LNNPL by $1.368 \%$. The result concurs the study of Nkusu (2011) and Farhan et al. (2012). Increase in interest rate will reduce the capability of borrowers to make repayment of the loans and loans subsequently turned sour. The cost of borrowing is increased because the banks tend to charge high lending rates given the high risk involved. To make the situation worst, during economic downturn unsettle loans problem may extremely arise due to problem of loan collections.

Income Distribution, LNID is significant and positively related to LNNPL at $1 \%$ significant level. A $1 \%$ increase in LNID will increase NPLs by some $0.086 \%$. Rinaldi \& Sanchis-Arellano (2006) conduct a study in the European countries to know the relationship between household and non-performing loans and concur that jobless, disposable income and financial conditions have a positive connection to NPLs. In the case of housing sector, the household units are likely not the primary holders of the assets as the buying intention is not due to investment purposes but to enjoy the high disposable income via increased debts.

Interestingly, contrary to our expectation, inflation is insignificant and do not appear to affect NPLs. The result is in line with Fofack (2005) and Khemraj, Tarron \& Pasha (2009). Fofack (2005) has discovered that NPLs in some CFA countries in Africa were not affected by inflation variable. In fact, the Sub-Saharan Africa banking crisis of the 90s was not inflationary prone as inflationary prone crisis maybe the result of expansionary monetary policy and through rapid increase in domestic credits. The dynamic of NPLs for these countries is best explained by the growth rate of GDP. Khemraj, Tarron \& Pasha (2009) evidenced the same insignificant relationship and conclude that inflation is not an important determinant of NPLs in the Guyanese banking system.

\section{Short Run Elasticities and Error Correction Term for Model of Non-Performing Loans}

Lastly, Table 5 states the results of short-run elasticities and error correction term (ECT). In term of short run, the LNGDP and LNINF has a significant negative relationship with LNNPL. Nevertheless, LNBLR and LNID resulted in an insignificant relationship with LNNPL. Based on the coefficient, an increase in GDP by $1 \%$ will decrease NPLs by $0.39 \%$. For Inflation, LNINF showed a significant negative relationship to the LNNPL in Malaysia at a 5\% significant level. An increase of $1 \%$ in INF will decrease NPLs by $0.03 \%$ as shown by the coefficient.

The implication of the models is that any one of the variable can be targeted as a policy variable to found out the changes in other variables in the system by using the cointegration method. In other words, it means that any changes in dependent variables are connected to the changes in the other independent variables in the system. The changes in the DV also influence the level of instability in the cointegrating connection, as shown by the error correction term (ECT). Table 5 above shows the ECT in ARDL regression for the entire variable and shows a negative and statistically significant, which is the criteria for model stability. Essentially, the result from the cointegration model, t-statistics on lagged residual of the ECM is statistically significant thus strengthening the study. Changes of the variables to converge in the long run are represented by a high value of coefficient. Given an ECT of -0.40 , it means that $40 \%$ of the adjustment and needs 2.5 quarters to become equilibrium so as to complete in a year due to short-run adjustment is considered very rapid. Finally, the size of R-square 
INTERNATIONAL JOURNAL OF ACADEMIC RESEARCH IN BUSINESS AND SOCIAL SCIENCES Vol. 8, No. 10, Oct. 2018, E-ISSN: 2222-6990 @ 2018 HRMARS

is good at $99 \%$ indicating that $99 \%$ of the dependent variables can be explained by the independent while the other $1 \%$ is affected by other variables not included in the model.

Table 5: Results for Short Run Elasticities and Error Correction Term for Model of Non-Performing Loans

\begin{tabular}{lcccc}
\hline Variable & Coefficient & Std. Error & t-Statistic & Prob. \\
\hline D(LNGDP) & -0.393812 & 0.162222 & -2.427615 & $0.0248^{* *}$ \\
D(LNGDP(-1)) & 0.293975 & 0.189326 & 1.552743 & 0.1362 \\
D(LNINF) & -0.035950 & 0.017031 & -2.110941 & $0.0476^{* *}$ \\
D(LNINF(-1)) & -0.002375 & 0.012368 & -0.192014 & 0.8497 \\
D(LNINF(-2)) & 0.043059 & 0.011821 & 3.642541 & $0.0016^{* * *}$ \\
D(LNBLR) & 0.098416 & 0.217243 & 0.453022 & 0.6554 \\
D(LNBLR(-1)) & -0.669710 & 0.329781 & -2.030769 & $0.0558^{*}$ \\
D(LNBLR(-2)) & 0.237348 & 0.217950 & 1.089002 & 0.2891 \\
D(LNID) & 0.001019 & 0.003914 & 0.260270 & 0.7973 \\
D(LNID(-1)) & -0.011617 & 0.004269 & -2.721107 & $0.0132 * *$ \\
D(LNID(-2)) & -0.014236 & 0.004504 & -3.160699 & $0.0049 * * *$ \\
CointEq(-1) & -0.396717 & 0.095396 & -4.158628 & $0.0005^{* * *}$ \\
\hline Cointeq = LNNPL -(-2.6057*LNGDP + 1.3685*LNBLR - 0.0604*LNINF + 0.0865*LNID + 30.3622) \\
\hline R-squared & 0.998837 & & \\
Adjusted R-squared & 0.997906 & & \\
\hline a P-values are in parentheses. & & \\
$* * *$ Significant at 0.01 level, ** Significant at 0.05 level, * Significant at 0.10 level. & \\
\end{tabular}

\section{RECOMMENDATION AND CONCLUSION}

In this paper, we empirically study the factors that cause the movement of non-performing loans (NPLs) in the banking and financial institutions in Malaysia. This paper adds to the existing NPLs literature by considering the macroeconomic determinants of NPLs in the Malaysian environment using the Auto-Regressive Distributed Lag (ARDL) approach. ARDL method was employed to see the significant relationships between dependent and independent variables in long run and short run elasticity for a set of time series data from Q12006 to Q42015 in Malaysia. The study concludes that the level of NPLs in Malaysia is affected by the macroeconomic conditions namely Gross Domestic Product (GDP), Base Lending Rate (BLR), Inflation (INF) and Household Income Distribution (HPI). While results for all the variables are in line as per expectation, it is interesting to note that contrary to our expectation, inflation is insignificant and do not appear to affect NPLs in Malaysia.

Results of the study can help policymakers such as the Central Bank of Malaysia to formulate guidelines to prevent or control NPLs problems. Financial institutions can reduce the NPLs while increasing the bank's performance. The study recommends that in order to improve the banking and 
financial institutions NPLs in Malaysia, the Central Bank need to monitor and supervise the monetary regulation to control the lending interest rate in the country. Low level of interest rate helps the institutions to minimize the level of NPLs in the country since there is positive relationship with NPLs. Furthermore, improvement of the country's economy is the key to lower NPLs figures. In general, improvement in the economy of the country increases the capability of the borrower due to increase in income thus the borrower able to repay the debts, and subsequently increase the financial stability. Thus, increase in GDP will reduce the NPLs ratio since there is negative relationship among them. In view of the positive relationship between household income distribution and NPLs, the Central Bank can revise and monitor the lending policy for commercial banks and other financial institutions. The bank must identify the real purpose of borrowings before approving their loans as to ensure a more productive usage of funds that directly link to economic activities.

For future studies, researchers can adopt different models for robustness purposes, and simultaneously add more macroeconomic variables such as exchange rate, money supply, unemployment rate, foreign direct investment or many more. In addition, researchers can further enlarge the research area such as to other Asian countries.

\section{Corresponding Author}

Amirudin Mohd Nor

Faculty of Business and Management

Universiti Teknologi MARA, Melaka

Malaysia

Email: amirudinmohdnor@gmail.com

\section{References}

Badar, M., \& Yasmin, J. A. (2013). Impact of Macroeconomic Forces on Nonperforming Loans: An Empirical Study of Commercial Banks in Pakistan. WSEAS Transactions on Business and Economics, 10(1), 40-48.

Bayoumi, T., \& Melander, O. (2008). Credit Matters: Empirical Evidence on U.S. Macro-Financial Linkages. IMF Working Paper WP/08/169.

Bebczuk, R., \& Cavallo, E. (2016). Is Business Saving Really None of Our Business? Applied Economics, 48(24), 2266-2284.

Beck, R., Jakubik, P., \& Piloiu, A. (2013). Non-performing loans: What Matters in Addition to the Economic Cycle? European Central Bank Working Paper Series 1515.

Blanco, R., \& Gimeno, R. (2012). Determinants of Default Ratios in the Segment of Loans to Households in Spain. Banco de España Working Paper Series 2012.

Espinoza, R., \& Prasad, A. (2010). Nonperforming Loans in the GCC Banking System and their Macroeconomic Effects. IMF Working Papers, 25.

Farhan, M., Sattar, A., Chaudhry, A. H., \& Khalil, F. (2012). Economic Determinants of Non-Performing Loans: Perception of Pakistani Bankers. European Journal of Business and Management, 4(19), 87-99.

Fofack, H. (2005). Nonperforming Loans In Sub-Saharan Africa : Causal Analysis And Macroeconomic 
INTERNATIONAL JOURNAL OF ACADEMIC RESEARCH IN BUSINESS AND SOCIAL SCIENCES

Vol. 8, No. 10, Oct. 2018, E-ISSN: 2222-6990 @ 2018 HRMARS

Implications. World Bank Policy Research Working Paper 3769.

Gaganis, C., Pasiouras, F., Doumpos, M., \& Zopounidis, C. (2010). Modelling Banking Sector Stability with Multicriteria Approaches. Technical University of Crete, Greece Working Paper 2010.01.

Greenidge, K., \& Grosvenor, T. (2010). Forecasting Non-Performing Loans in Barbados. Journal of Business, Finance \& Economics in Emerging Economies, 5(1), 79-108.

Ismail, N., Azlan, N. D. A., Husin, M. M., Ishak, I., \& Hashim, S. L. M. (2017). Bank Efficiencies and NonPerforming Loan of Commercial Banks in Malaysia. Journal of Humanities, Language, Culture and Business (HLCB), 1(5), 34-40.

Jakubík, P., \& Reininger, T. (2014). What Are the Key Determinants of Nonperforming Loans in CESEE? IES Working Paper Series, 1-25.

Jiménez, G., \& Saurina, J. (2006). Credit Cycles, Credit Risk, and Prudential Regulation. International Journal of Central Banking, 2(January), 65-98.

Khemraj, Tarron \& Pasha, S. (2009). The Determinants of Non-Performing Loans: an Econometric Case Study of Guyana. MRPA Working Paper No 531128.

Klein, N. (2013). Non-Performing Loans in CESEE: Determinants and Impact on Macroeconomic Performance. IMF Working Papers, 13(72), 1.

Louzis, D. P., Vouldis, A. T., \& Metaxas, V. L. (2012). Macroeconomic and Bank-Specific Determinants of Non-performing Loans in Greece: A Comparative Study of Mortgage, Business and Consumer Loan Portfolios. Journal of Banking and Finance, 36(4), 1012-1027.

Nkoro, E., \& Uko, A. K. (2016). Autoregressive Distributed Lag (ARDL) Cointegration Technique: Application and Interpretation. Journal of Statistical and Econometric Methods, 5(4), 63-91.

Nkusu, M. (2011). Nonperforming Loans and Macrofinancial Vulnerabilities in Advanced Economies. IMF Working Papers Vol. 29.

Pesaran, M. H., Shin, Y., \& Smith, R. J. (2001). Bounds Testing Approaches to the Analysis of Level Relationships. Journal of Applied Econometrics, 16(3), 289-326.

Rinaldi, \& Sanchis-Arellano. (2006). Household Debt Sustainability: What Explains Household Nonperforming Loans? An Empirical Analysis. ECB Working Paper.

Shingjergji, A. (2013). The Impact of Macroeconomic Variables on the Non Performing Loans in the Albanian Banking System During 2005 - 2012. Academic Journal of Interdisciplinary Studies, 2(9), 335-339.

Skarica, B. (2014). Determinants of Non-Performing Loans in Central and Eastern European Countries. Financial Theory and Practice, 38(1), 37-59.

Sufian, F., Kamarudin, F., \& Nassir, A. Md. (2016). Determinants of Efficiency in the Malaysian Banking Sector: Does Bank Origins Matter? Intellectual Economics, 10(1), 38-54. 